\title{
INTERNATIONAL MOBILITY AND EDUCATIONAL TOURISM. CASE STUDY: ERASMUS PROGRAM AT U.S.A.M.V. IAȘI
}

\author{
Cezara DULCE \\ „Alexandru Ioan Cuza” University of Iaşi, Faculty of Geography and Geology, Department of Geography, \\ 20A Carol I Av., 700505, Iași, Romania, e-mail: cezara.dulce@yahoo.com \\ Ionel MUNTELE* \\ „Alexandru Ioan Cuza” University of Iaşi, Faculty of Geography and Geology, Department of Geography, \\ 20A Carol I Av., 700505, Iaşi, Romania, e-mail: imuntele@yahoo.fr
}

Citation: Dulce, C., \& Muntele, I. (2021). INTERNATIONAL MOBILITY AND EDUCATIONAL TOURISM. CASE STUDY: ERASMUS PROGRAM AT U.S.A.M.V. IAȘI. Analele Universităţii din Oradea, Seria Geografie, 31(2), 143-152. https://doi.org/10.30892/auog.312105-871

\begin{abstract}
Regardless of which perspective is analysed, in or out - going, the educational tourism in the city of Iasi is strongly related to its status as a regional center of educational polarization. Our objective is to analyse and inventorize the evolution of Erasmus international mobilities of "Ion Ionescu de la Brad" University of Agricultural Sciences and Veterinary Medicine Iasi between 2013 and 2019. These mobilities, along with school trips, travels for seminars, conferences or symposiums, language schools and educational events shape the educational tourism in the city of Iasi. Our study is based on the statistical provided by the International Relations office of the university. The first step in our research was the investigation of the specialised literature, we continued with the analysis of the statistical data related to this subject and the creation of graphic and cartographic materials. The study area is the city of Iasi. The interpretation of the obtained results highlights a series of transformations, as the increase in the number of Erasmus+ international mobilities. This is a sign that educational tourism has a growing interest from students of this university, being an important element of the tourism development strategy of the city.
\end{abstract}

Key words: educational tourism, international cultural exchanges, internships, Erasmus mobilities

$* \quad * \quad * \quad * \quad * \quad *$

\section{INTRODUCTION}

As countries become more and more independent, the success, development and the economic prosperity depend to a large extent on the ability of two industries - education and tourism in order to create the revenue needed to support international sustainable trade and learning (Bowan $\&$ Dallam, 2020). The tourist experience, knowing the tourist destination and local communities are today defining elements in the practice of tourism. The forms of alternative tourism (where educational tourism is an important component) satisfy such requests.

Although the concept of educational tourism and specialized tourism products are recently beginning to take shape worldwide, educational travel has been going on for centuries, education within

\footnotetext{
${ }^{*}$ Corresponding author
} 
universities located outside the tourist residence, product of the educational tourism industry (edu tourism), being today a multi-billion dollar business at global level (Mok \& Cheung, 2011). Considered a niche tourism, this form has been gainig ground in the context of globalization (Novelli, 2005).

Educational tourism is defined as a tourist activity carried out by people who spend at least one night in accommodation facilities or by those who participate only in a trip to the destination region and for whom learning is the main or second motivation for travelling (Ritchie, 2003).

It is also a program through which participants travel to a location as a group, with the primary goal of engaging in a learning experience which is directly related to that location (Bodger, 1998) and it can range from general interest while traveling to purposeful learning (Maga \& Nicolau, 2018).

In general, the activities of edu-tourism (educational tourism) include primarily conferences participation, study tours for adults, studies at universities inside or outside borders and secondly school trips or international mobilities programs (Ojo \& Rajayuso, 2019).

Globally, there are countries that host quality higher education institutions such as the United Kingdom of Great Britain and Northern Ireland (the birthplace of this form of tourism) or the United States of America. Given current trends and the approach of Brexit, Germany, which also stands out, is on the verge of overtaking the United Kingdom as the number one nation in Europe regarding the higher education domain, just like Switzerland and Canada.

There are many examples in the world. We have identified, for instance, the longest educational programs taking place in prestigious educational institutions.

Table 1. Educational tourism programs worldwide

Data source: after Dan Mihai Gherțoiu, Geographical bases of niche tourism (Ghertoiu, 2014)

\begin{tabular}{|c|c|c|c|}
\hline No. & University and Program & Country & Description \\
\hline 1. & $\begin{array}{l}\text { Educational Tourism } \\
\text { Program, University of } \\
\text { Cambridge }\end{array}$ & $\begin{array}{l}\text { United Kingdom of } \\
\text { Great Britain and } \\
\text { Northern Ireland }\end{array}$ & $\begin{array}{c}\text { Camps for young people (10-20 years) - English language } \\
\text { courses (grammar, cultural English, Shakespeare, Cambridge } \\
\text { writers, etc); rates - between } 900 \text { euros ( } 1 \text { week) and } 2800 \text { euros } \\
\text { ( } 4 \text { weeks); }\end{array}$ \\
\hline 2. & $\begin{array}{l}\text { Educational tourism } \\
\text { program, University of } \\
\text { Oxford - Management and } \\
\text { theater in Oxford }\end{array}$ & $\begin{array}{l}\text { United Kingdom of } \\
\text { Great Britain and } \\
\text { Northern Ireland }\end{array}$ & $\begin{array}{c}\text { Program for children ( } 12-15 \text { years old), young people (over } 16 \\
\text { years old) and adults (over } 30 \text { years old) }\end{array}$ \\
\hline 2.1. & $\begin{array}{l}\text { Educational tourism } \\
\text { program, University of } \\
\text { Oxford - International } \\
\text { Student Lyceum }\end{array}$ & $\begin{array}{l}\text { United Kingdom of } \\
\text { Great Britain and } \\
\text { Northern Ireland }\end{array}$ & $\begin{array}{c}\text { Program for children (over } 16 \text { years) - business, management } \\
\text { and culture (photography, creation, film, theater, } \\
\text { communication, etc) }\end{array}$ \\
\hline 3. & $\begin{array}{c}\text { Educational tourist } \\
\text { program - French language }\end{array}$ & France & Program for children (10-14 years) - learning French; \\
\hline 4. & $\begin{array}{l}\text { Educational tourism } \\
\text { program - Girls' School }\end{array}$ & Switzerland, Montreux & $\begin{array}{c}\text { Program for girls and teenagers (10-22 years old) - courses in } \\
\text { good manners, horse riding, tennis, water skiing, ceramics, } \\
\text { design, piano, etc; } \\
\text { Rates - } 6000 \text { Swiss francs (3 weeks) }\end{array}$ \\
\hline 5. & $\begin{array}{l}\text { Educational tourism } \\
\text { programs - Dublin }\end{array}$ & Ireland, Dublin & $\begin{array}{l}\text { Learning English (program that includes: English lessons, type } \\
\text { of accommodation and meals chosen, sports, social activities, } \\
\text { excursions, permanent supervision and medical care etc) }\end{array}$ \\
\hline
\end{tabular}

Moreover, the main destinations for educational trips are schools, institutions, universities, historical sites and famous school campuses. It is expected that each participant will be able to acquire skills and knowledge during the tours. It is believed that an educational tour leads to the enrichment of a person's knowledge and can improve the tourism products of the local tourism industry (Wang, Xiang, \& Yunpeng, 2013).

Educational tourism is focused on the basic needs of students: psychological, psycho-physical, emotional, social expressions, the need for change, the need for self-esteem, intellectual development, exploration and development of creative potential (Dembovska, Silicka, \& Lubkina, 2017). It also contributes to formation, acquisition and development of essential qualities of a person that are expressed in the form of universal, general professional and specialized skills (McLagan, 1997). 
Thus, student mobility (national and international/interregional) is important not only from an educational point of view but also from a tourist point of view. Students often choose universities not from the perspective of the advantages offered by the institution but from the perspective of the attractions that university cities provide and even more, educational mobility generates additional income for tourist destinations. As a result, educational tourism should be seen as an important element of the tourist destination management (Árva \& Könyves, 2010).

In the category of international mobilities are also Erasmus internships, which along with school trips, travels to seminars, conferences or symposia, language schools and educational events shape the educational tourism in Iasi, the study area for our research. Iasi is a university city with six universities (five public institutions and a private one) and for the academic year 2018/2019 it had about 55,000 students according to CNFIS (CNFIS, 2020).

We focused on the Erasmus + 2014-2020 program as it covers most of the analysis period of our study, 2013/2019. The Erasmus program was born in 1987 and offers to students the opportunity to study in a European country for a certain period, a period that is later formally recognized by the host institution (Erasmus Program History, 2020).

Following its evolution over time, the following programs are scored: Erasmus Socrates (2000-2007); Erasmus Lifelong Learning Program (2007-2014, study mobility and university staff in well-known universities in Europe); Erasmus + (2014-2020, mobility individual students and university staff), with new directions: inter-institutional cooperation, exchange of good practices at international level and support for institutional policy reforms.

Therefore, the Erasmus+ program is the European Union's program for education, training, youth and sport in Europe. With a budget of $€ 14.7$ billion, it will give more than 4 million Europeans the opportunity to study, train and gain experience abroad (European Commission, 2020). 34 countries are currently participating. It brings together seven European Union programs in the field of education, training, youth and supports, for the first time, sport. The seven European funding programs together are: Lifelong Learning, Youth in Action, Erasmus Mundus, Tempus, Alpha, Edulink and the cooperation program with industrialized countries (University of Bucharest, 2020). However, educational tourism is little studied, although there is no lack of attempts to draw up its own theory and methodology (McGladdery \& Lubbe, 2017). From a statistical point of view, the significant figures for the Erasmus+ program (2014/2020) are the following:

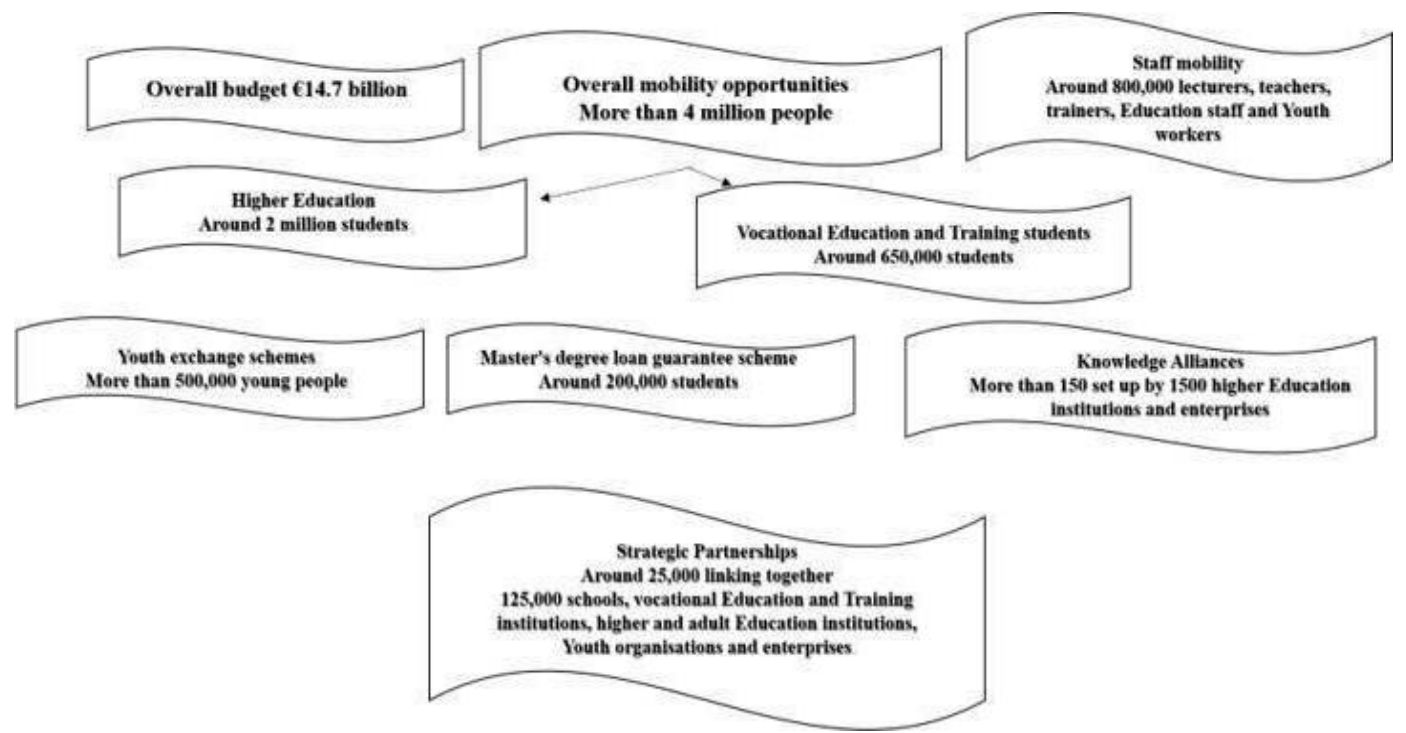

Figure 1. Erasmus + program in figures, 2014-2020

Data source: after Erasmus Plus, relevant figures (Erasmus Plus, 2020) 


\section{METHODOLOGY}

The methods used are: geographical (complex approach of higher education tourism phenomenon in the territory) and analytical (detailed analysis of the components of higher education tourism as a tourist activity: in this case - Erasmus international mobilities of students from "Ion Ionescu de la Brad" University of Agricultural Sciences and Veterinary Medicine Iasi).

Furthermore, we used the synthetic (detailed analysis of the educational tourism components at a global, regional and local level and the integration of the partial information in a unitary representation, highlighting the complexity of the analyzed tourist phenomenon: in this case international student mobilities) and cartographic methods (using specialized softwares, such as PhilCarto and Adobe Illustrator).

Regarding the means, we used bibliographic sources, mediated collection techniques (reports and statistical data from the International Relations Offices of the analyzed university), specialized software (ArcGis, Phil Carto, Adobe Illustrator) and classic ones (Microsoft Office Package).

In this study we start from a general hypothesis: formal education in classrooms is not enough today, students' preferences are much more diversified; therefore, activities in which students can get involved, in which they can learn and acquire new knowledge, skills and abilities are requirements that only specialized forms of tourism (in this case, higher education tourism) can fullfil.

Our working hypothesis is: the increasingly active participation of students in Erasmus study and practice programs on both Incoming and Outgoing components between 2013 and 2019 within "Ion Ionescu de la Brad" University of Agricultural Sciences and Veterinary Medicine Iasi is an impetus for the development of educational tourism in the municipality. Finally, the hypothesis will be confirmed or invalidated, based on the research results.

The work objective established within the research is to analyze and inventorize the evolution of Erasmus international mobilities registered in this university between 2013 and 2019.

The data provided by the International Relations Office covers the period between 2013 and 2019 (just to capture the beginning of the Erasmus+ program) and consists of specific information related to the number of students who accessed an Erasmus study and practice mobility between 2013 and 2019 by the two components, Outgoing and Incoming from and to the Romanian territory.

\section{RESULTS AND DISCUSSIONS}

"Ion Ionescu de la Brad" University of Agricultural Sciences and Veterinary Medicine had much smaller numbers of participants in Erasmus international mobilities compared to "Alexandru Ioan Cuza" University, one of the most prestigious higher education institutions in Romania and the first public university in Iasi regarding Erasmus international mobilities. The annual average is around 32 participants (in the case of the Incoming department) and 50 participants (in the case of the Outgoing department), by both components: Study and Practice. However, the distribution of student flows may be of comparative interest or may indicate the presence of specific destinations, which is why the case study was considered necessary. The results are presented separately for each of the two departments: outgoing and incoming.

\section{Outgoing Department}

In the analyzed period, 2013-2019, in respect of the Outgoing component, the total number of participants in Erasmus international mobilities had an ascending route, starting from 44 participants in 2013/2014, with a peak of values in the academic year 2016/2017 (54 participants) and ending the 2018/2019 academic year with 49 students who chose an Erasmus mobility outside the country.

Interesting is the number of students who chose a study mobility abroad, which registers a continuous and sustained decline in the entire period, from 23 participants in 2013/2014 to only 8 participants in 2018/2019 (Figure 2). 


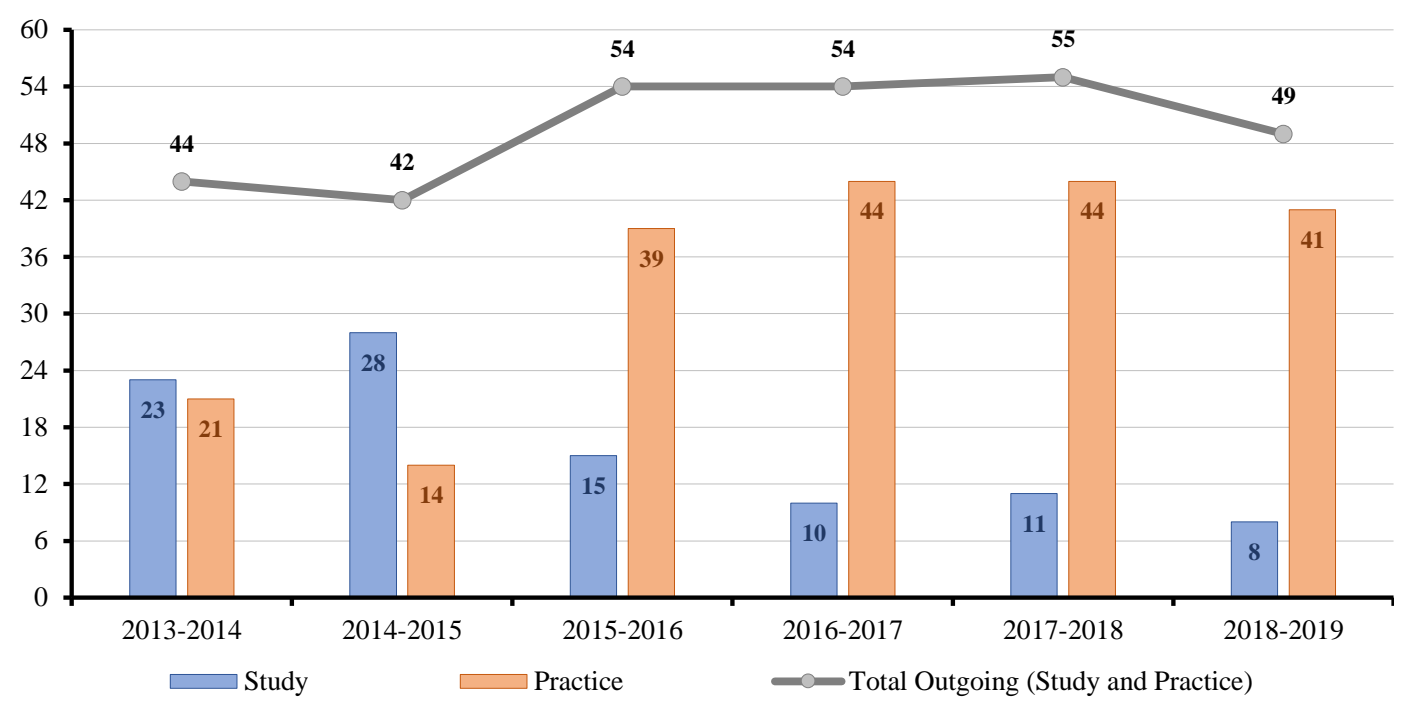

Figure 2. Study internships Erasmus Outgoing Study and Practice (2013/2019) Data source: U.S.A.M.V. "Ion Ionescu de la Brad” Iași (International Relations Office, 2020)

One explanation is that students are rather attracted by a placement mobility/internship (where they can have a double advantage: obtaining professional experience and a salary) but also the number of bilateral agreements between "Ion Ionescu de la Brad" University and the other institutions from the partner countries. We outline a number of 20 partner states, compared to 45 ones registered by "Alexandru Ioan Cuza" University (however, the higher number of faculties and specializations of the university must be also taken into account).

Other reasons for the students' choices could be the distance from the destination country and the non - attractive study programs provided by foreign institutions. The compatibility of the study programs is also a frequently cited cause. In some cases it is difficult to equate courses or grant credits. This also explains the preference for internship programs, which are easier to equate. Some studies indicate a link between the compatibility of study programs and the size of student exchanges (Quezada, 2004).

In respect of the Outgoing component, in 2013/2014 (the beginning of the program) the Romanian students accessed 8 foreign countries and the highest shares of participants were held by Italy (34\%), followed by France (20\%), Spain and Greece (each with about 14 percent). In the end of the analyzed period, 2018/2019, the total number slightly increased, reaching the total number of 10 countries chosen by the Romanian students.

Throughout the analyzed period, constant flows of Romanian students went to Italy, Spain, Turkey and Germany, mainly for an internship, as a result, just like in the case of the Incoming component, of the old partnerships between institutions. Greece and Portugal can also be mentioned in this category, without the academic year 2013/2014. Options for an internship (placement mobility) or study were also Croatia, Poland or the Netherlands, which received Romanian students during the 2016/2017 and 2017/2018 periods (Figure 3). The study program followed is important in choosing the destination, southern European countries being accessed especially by students in horticulture and northern countries by those in veterinary medicine and animal husbandry.

New countries appear on the destination map, which in the future could have important flows of participants, as, for example, the Czech Republic and Estonia. The spreading area of the Erasmus Outgoing phenomenon goes beyond southern and central Europe, respectively towards the north and west of the continent. Therefore, the students of this university may enjoy new study and practice opportunities. 
The previously visible unidirectional concentration of flowssuffered a significant dispersion during this time interval. In several years, departures were registered towards the other states with which there are agreements, as mentioned on the map. The most attractive states have consistently maintained their preferred destination status.

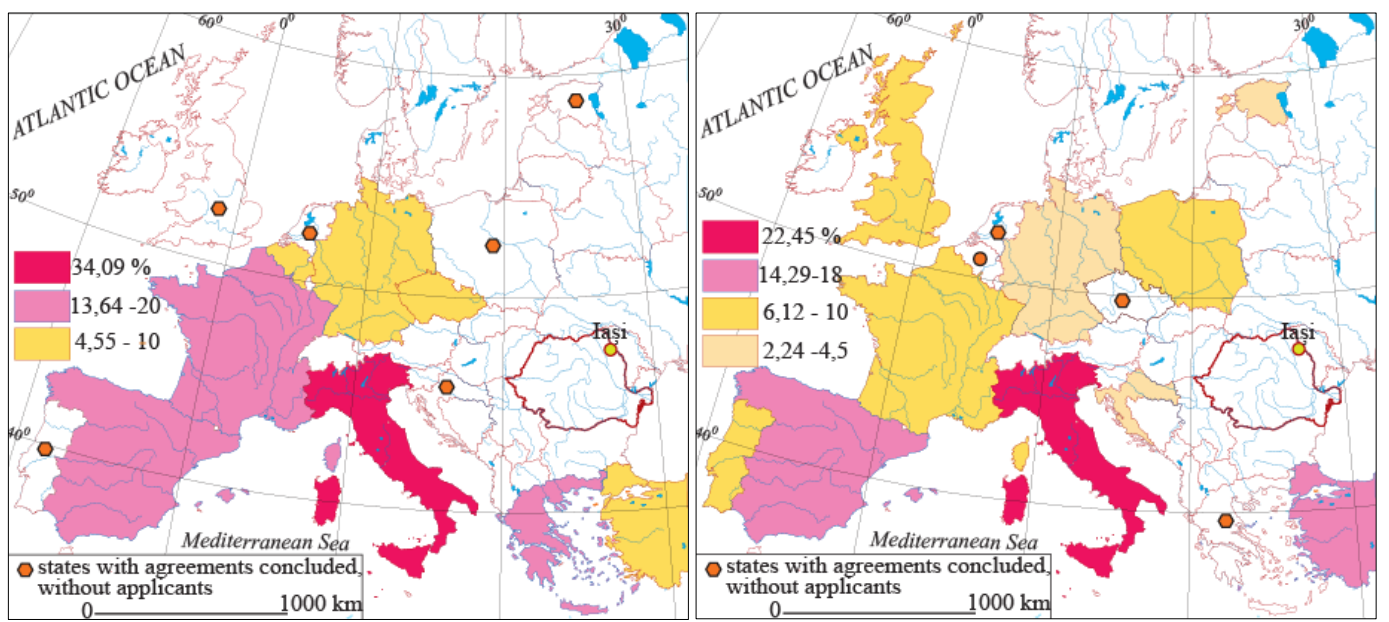

Figure 3. The percentage of the Erasmus Outgoing participants for each destination country in 2013/2014 (left) and 2018/2019 (right)

Data source: U.S.A.M.V. "Ion Ionescu de la Brad” Iași (International Relations Office, 2020)

\section{Incoming Department}

As regards the Incoming component, throughout the analyzed period (2013/2019) the total number of participants in international Erasmus mobilities recorded a constantly ascending trend during the first five years and a slightly descending one in the last year, starting from 22 participants in 2013/2014, with a peak of values in the academic year 2017/2018 (48 participants) and ending the academic year 2018/2019 with 37 foreign students who had chosen an Erasmus mobility abroad (Figure 4).

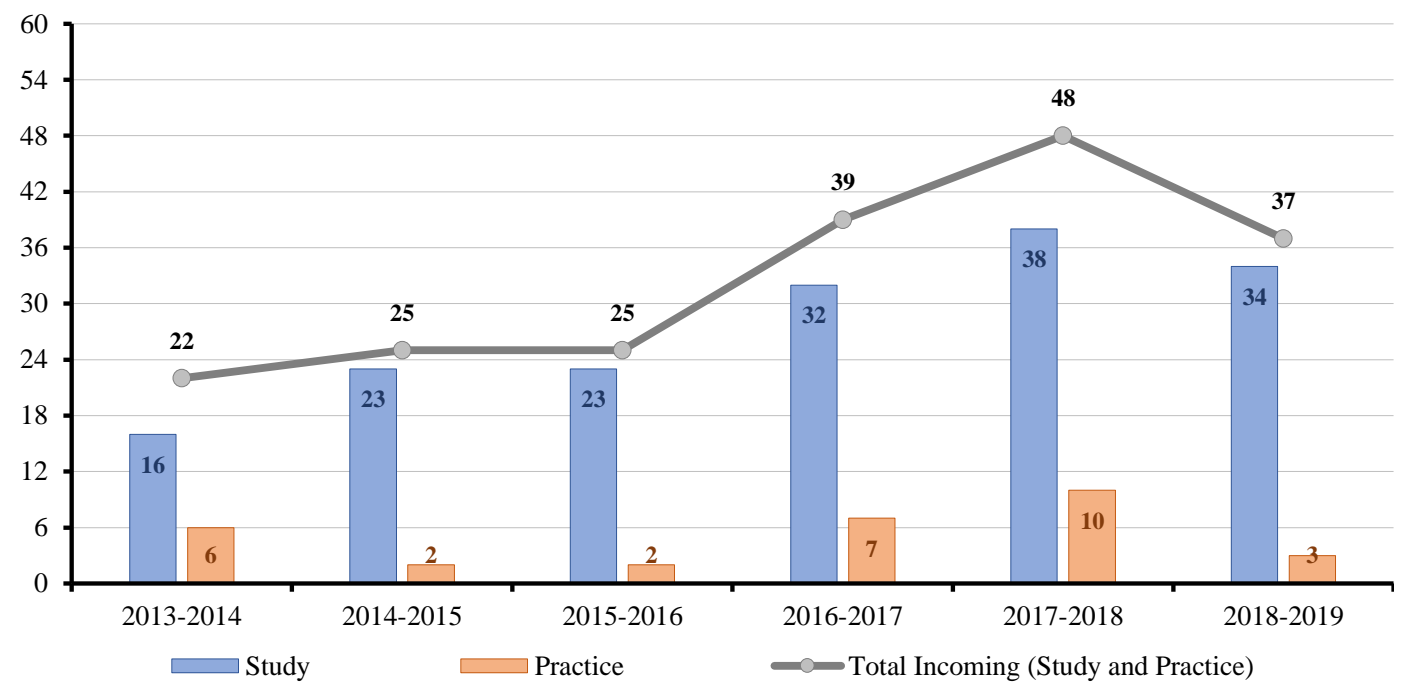

Figure 4. Study internships Erasmus Incoming Study and Practice (2013/2019)

Data source: U.S.A.M.V. "Ion Ionescu de la Brad” Iași (International Relations Office, 2020) 
Unlike the previous component (Outgoing), the study mobilities were attractive for foreign students, the faculties and specializations within Ion Ionescu de la Brad University providing new opportunities for them. The total number of participants experienced an ascending trend, starting from 16 foreign students in 2013/2014 and ending the academic year 2018/2019 with 34 students, except for the last academic year, with registered a slight decrease of 4 students. Similarly to the Outgoing component, the distance between the origin countries and our country and the attractiveness of study and placement programs provided by the Romanian institution are important pull factors for the foreign students. At the beginning of the program, 2013/2014, foreign students arrived from 4 countries (Italy, Spain, Turkey and Portugal) and in the end of the analyzed period, $2018 / 2019$, the number slightly increased to 7 countries. The partner countries category enlarged with Poland, Greece and the Netherlands. If we refer to fluctuations, we can mention that in the next two years of the study period, the university also received students from Poland.

Only in the academic year 2016/2017 the university received students from France, the Czech Republic and the Netherlands, while for Greek and Dutch students our university was an Erasmus destination in 2016/2017 and 2018/2019. The highest shares are held by Portugal, followed by Turkey and Italy, as a result of the old partnership between foreign and Romanian institutions, shares that relatively remain constant, despite the slight fluctuations during the entire period (Figure 5).

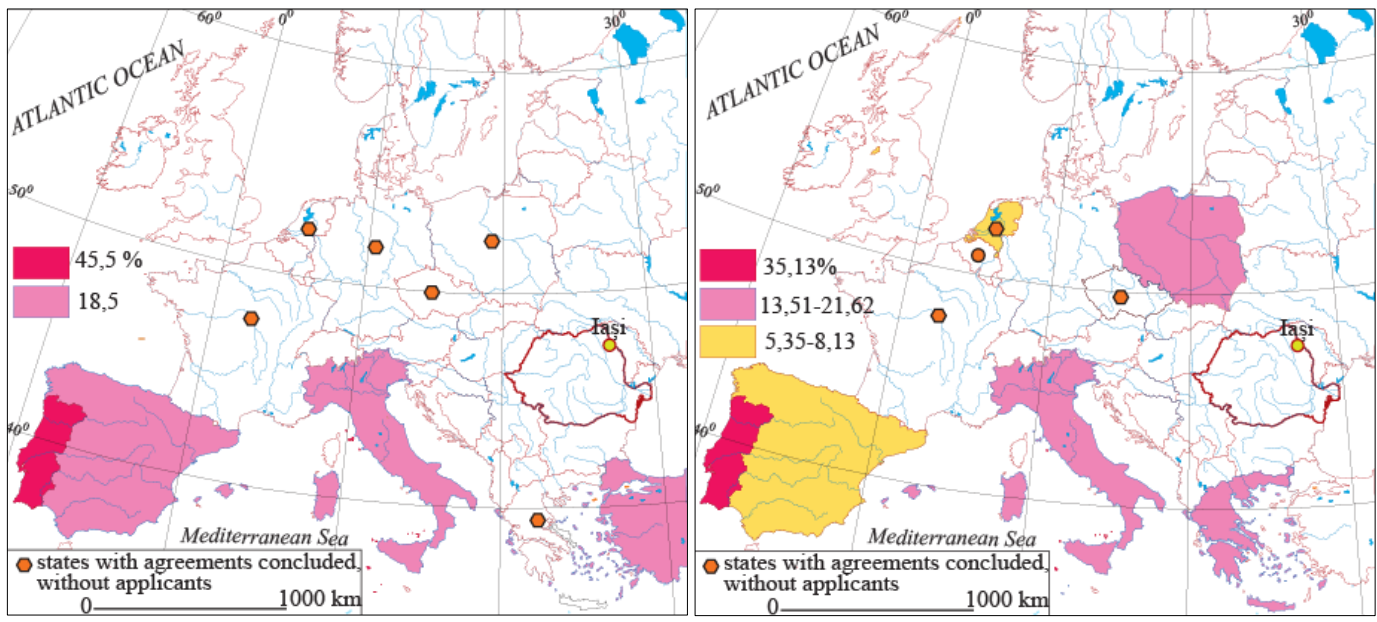

Figure 5. The percentage of the participation of the Erasmus Incoming Study for each destination country in 2013/2014 (left) and in 2013/2014 (right)

Data source: U.S.A.M.V. “Ion Ionescu de la Brad” Iași International Relations Office

The concentration of arrivals flows is much stronger than in the case of departures and can be correlated with the specificities of the agricultural higher education, whose attractiveness is lower today. The place occupied by Portugal, despite the distance that separates it, does not seem to be accidental if we refer to certain similarities such as the high share of the rural population or of the people working in agriculture, as in other states or regions in the south of the continent. In this case, the slight dispersion to the northwest of Europe, more urbanized and with a highly industrialized agriculture, becomes explicable.

The total number of students participating in an international Erasmus mobility at "Ion Ionescu de la Brad" University (both Incoming and Outgoing components) has a slightly ascending course between 2013 and 2019, a peak of values being registered in the academic year 2017/2018 (over 100 participants, as a result of capitalizing partnerships by the university and opportunities by the Romanian/foreign students). 
The spreading area does not expand beyond the European continent (significant numbers of students heading to Italy, Portugal, France or Spain and arriving from the same countries). The only exception is Turkey, where important and constant flows are involved in Erasmus mobilities; however, this is debatable since the context is mainly attributable to its European part.

Gathering the data on the Erasmus international mobilities to and from "Ion Ionescu de la Brad" University of Agricultural Sciences and Veterinary Medicine Iasi between 2013/2014 and $2018 / 2019$, the hypothesis launched at the beginning of our study is confirmed: the increasingly active participation in study programs and student practice on both components (Incoming) and Outgoing between 2013/2019 within the university is an impetus for the development of educational tourism in the city (Figure 6).

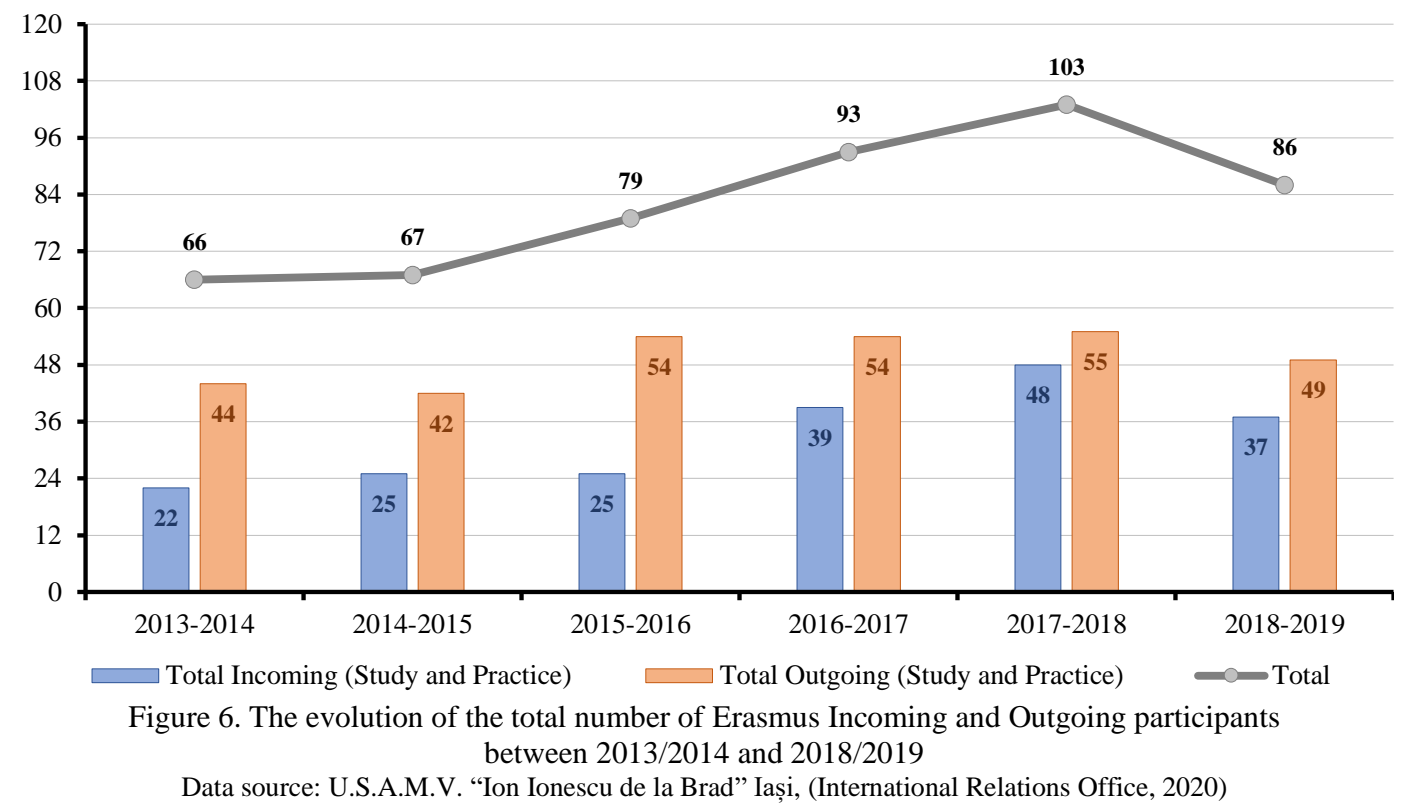

The analysis of the flows generated by the Erasmus+ exchanges in the case of this university from Iasi highlights a lower dispersion and attractiveness corresponding to its share in the local higher education. Its strong specialization and the particularity induced by agricultural activities reduce the possibility of establishing connections with states where agriculture has long been a secondary activity. This explains the preferential relations with the Southern or Eastern European states that have certain similarities. Beyond this specificity, the student exchanges to which this university is a partner represent an opportunity for tourism, in both directions, the number of participants working as indisputable image vectors.

\section{CONCLUSIONS}

Although educational traveling has had an old tradition which dates back to the seventeenth century, the concept of educational tourism is relatively new. Educational or edu tourism - tourism is born as a reaction to mass tourism (standardized) and responds to the new requirements of tourists: tourist experience, knowledge as closely as possible of the tourist destination and involvement in the life of local communities.

The main/secondary motivation is participating in a learning activity/an activity that involves acquisition of knowledge, skills or abilities. The main form of manifestation of educational tourism is the higher education tourism, more specifically international mobility programs for students in world famous higher education institutions and beyond. In fact, our paper is dedicated to this form 
of edu-tourism. This form of tourism can play a major role in raising academic standards, as some studies show (Smith, 2013).

Worldwide, the highest level of educational tourism is in countries with quality higher education institutions, such as the United Kingdom of Great Britain and Northern Ireland, the United States of America and Germany. For Romania and the city of Iasi, "Ion Ionescu de la Brad" University of Agricultural Sciences and Veterinary Medicine is placed on the forth position in Iasi regarding Erasmus international mobilities for students, teaching and university staff. Romanian students chose Italy, Spain, Turkey and Germany and foreign students arrived from Italy, Spain, Turkey and Portugal.

During the analyzed period, 2013/2019, Erasmus international mobilities increased, a fact that confirms the hypothesis launched at the beginning of our research. There is an increasingly active participation of students from the university in international mobility programs on both components (Incoming and Outgoing), which leads to the development of educational tourism in the city.

Acknowledgement: This contribution presents some results from research project Educational tourism in Iasi. Analysis for the period after integration within European Union.

\section{REFERENCES}

Árva, L., \& Könyves, E. (2010). Educational tourism and its effects on regional economy and destination management. In A. Clarke, Constructing Europe. Tourism management (pp. 283-298). Veszprem: Pannon University Conference Papers.

Bodger, D. (1998). Leisure, Learning and Travel. Journal of Physical Education, Recreation\&Dance, 69(4), 28-31. doi:10.1080/07303084.1998.10605532

Bowan, D., \& Dallam, G. (2020). Building bridges: overview of an international sustainable tourism education model. Journal of Teaching in Travel\&Tourism, 20(3), 202-215. doi:10.180/15313220.2020.1797609

CNFIS. (2020). Retrieved September 2020, from National Council for the Financing of Higher Education [CNFIS]: http://www.cnfis.ro/

Dembovska, I., Silicka, I., \& Lubkina, V. (2017). Educational tourism in the training of the future professionals. Proceedings of the International Scientific Conference. Society. Integration. Education, 4, pp. 245-255.

Erasmus Plus. (2020). Relevant figures. Retrieved September 2020, from https://www.erasmusplus.ro/cifrerelevante

Erasmus Program History. (2020). Retrieved November 2020, from https://www.mta.ro/international/erasmushistory-ro/

European Commission. (2020). Retrieved November 2020, from https://ec.europa.eu/programmes/erasmusplus/about_ro

Ghertoiu, D. (2014). Noi forme de turism dezvoltate după 1990. Turismul de nişă din România, [New forms of tourism developed after 1990. Niche tourism in Romania]. Doctoral Dissertation, Universitatea "BabeșBolyai", Cluj-Napoca.

International Relations Office. (2020). Iași: U.S.A.M.V. "Ion Ionescu de la Brad".

Maga, A., \& Nicolau, P. (2018). Conceptualizing Educational Tourism and the Educational Tourism Potential (evidence from ASEAN countries). Advances in Economics, Business and Management Research, 39, 343-348.

McGladdery, C., \& Lubbe, B. (2017). Rethinking educational tourism: new model and future directions. Tourism Review, 72(3), 319-329. doi:10.1108/TR-03-2017-0055

McLagan, P. (1997). Competencies the next generation. Training \&Development, 51(5), 40-46.

Mok, K., \& Cheung, A. (2011). Global aspirations and strategizing for world class status: new form of politics in higher education governance in Hong Kong. Journal of Higher Education Policy and Management, 33(3), 231-251. doi:10.1080.1360080X.2011.564998

Novelli, M. (2005). Niche Tourism: Contemporary Issues, Trends and Cases. Routledge. 
Ojo, B., \& Rajayuso, R. (2019). EDU - Tourism destination selection process in an emerging economy. Journal of Tourism Management Research, 6(1), 45-59. doi:10.18488/journal.31.2019.61.45.59

Quezada, R. (2004). Beyond educational tourism: lessons learned while student teaching abroad. International Education Journal, 5(4), 458-165.

Ritchie, B. (2003). Managing educational tourism. Sydney: Channel View Publications.

Smith, A. (2013). The role of educational tourism in raising academic standards. African Journal of Hospitality, Tourism and Leisure, 2(3), 1-7.

University of Bucharest. (2020). Retrieved November 2020, from https://unibuc.ro/international/

Wang, D., Xiang, L., \& Yunpeng, L. (2013). China's "smart tourism destination" initiative: A taste of the service-dominant logic. Journal of Destination Marketing\&Mangement, 2(2), 59-61. doi:https://doi.org/10.1016/j.jdmm.2013.05.004

Submitted:

February 10, 2021
Revised:

November 15, 2021
Accepted and published online

December 2, 2021 